\title{
Quality characteristics of lotus root (Nelumbo nucifera G.) snacks according to heat treatment methods and conditions
}

\author{
Ji-Young Choi ${ }^{1}$, Junghoon Park ${ }^{2}$, Jiyoon Kim ${ }^{1}$, Jungsoo Kim ${ }^{1}$, Saeul Jeong ${ }^{1}$, \\ Minhyun Kim ${ }^{1}$, Sanghyeok Park ${ }^{1}$, Kwang-Deog Moon ${ }^{1 *}$ \\ ${ }^{1}$ School of Food Science and Technology, Kynngpook National University, Daegu 41566, Korea \\ ${ }^{2}$ Novarex Research \& Development Center, Cheongju 28220, Korea
}

\section{열처리 방법 및 조건에 따른 연근스낵의 품질 특성}

\author{
최지영 ${ }^{1} \cdot$ 박정훈 $^{2} \cdot$ 김지윤 $^{1} \cdot$ 김정수 $^{1} \cdot$ 정새울 $^{1} \cdot$ 김민현 $^{1} \cdot$ 박상혁 $^{1} \cdot$ 문광덕 $^{1 *}$ \\ 1경북대학교 식품공학부 식품생물공학전공, ${ }^{2}$ 노바렉스 생명과학연구소
}

\begin{abstract}
This work investigated the effects of various heating methods and conditions on the quality characteristics of lotus root (Nelumbo nucifera G.) snack. The lotus root snacks were processed using the following heating methods: oven heating (OV), microwave heating (MW), air frying (AF), and oil frying (FR). Twenty four samples were prepared based on the various temperatures and time durations used for heating. Based on the results of color and hardness analyses, OV $\left(180^{\circ} \mathrm{C}, 9 \mathrm{~min}\right), \mathrm{MW}(850 \mathrm{~W}, 8 \mathrm{~min}), \mathrm{AF}\left(120^{\circ} \mathrm{C}, 10 \mathrm{~min}\right)$ and $\mathrm{FR}\left(180^{\circ} \mathrm{C}, 70 \mathrm{sec}\right)$ were selected as appropriate conditions for producing the lotus root snacks. AF resulted in low carbohydrate content, crude fat content, and neural detergent fiber content and the highest moisture content. There were no significant differences in hardness among four methods. $\mathrm{AF}\left(120^{\circ} \mathrm{C}, 10 \mathrm{~min}\right)$ showed significantly higher $\mathrm{L}^{*}$ values, total phenolics contents, and 2,2-dipheny-1-picrylhydrazyl, 2,2'-azino-bis(3-ethylbenzothiazoline- 6-sulphonic acid radical scavenging activity than other methods. In addition, water absorption and water solubility indexes were the lowest in $\mathrm{AF}$. Therefore, $\mathbf{A F}\left(120^{\circ} \mathrm{C}\right.$, $10 \mathrm{~min}$ ) was considered as an appropriate heating condition for the manufacturing of lotus root snacks.
\end{abstract}

Key words : lotus root, snack, heating method, air frying, water absorption index

\section{서 론}

연(Nelumbo nucifera G.)은 수상식물 중 부엽식물에 속하 는 쌍떡잎식물로서 주로 연못에서 자라고 논밭에서 재배되기 도 하며, 뿌리부분(연근)과 잎 부분이 모두 예로부터 식품 및 민간치료제로 사용되어 왔다(Kim 등, 2011a; Lee 등, 2006). 연의 국내 주산지는 2008년을 기준으로 경남이 $35 \%$, 대구가 $33 \%$, 경북이 $15 \%$ 를 차지하여, 주로 경상남북도에서 재배하 고 있는 것으로 나타났다. 2010년 한국농촌경제연구원의 발
표에 따르면, 전국적으로 연 재배면적은 2008년을 기준으로 $625 \mathrm{ha}$ 로 2001년에 $197 \mathrm{ha}$ 인 것에 비하면 3배 이상 증가하 였으며, 그 이후에도 계속해서 증가 추세를 보였다. 생산량 역시 계속해서 증가하는 현상을 보였으나, 연을 이용한 상품 화는 일반식품 위주의 단순한 단계에 머무르고 있는 수준이 며, 고부가가치 산업으로 발전하기 위한 추가적인 연구 사례 가 부족한 실정이다. 따라서 연은 지역별 특성에 따라 소득화 가 가능한 지역특산물, 식품 소재 및 가공 제품 개발 등의 다양 한 용도로 활용되어야 한다. 특히 연 이용 부위가 대부분 연근

*Corresponding author. E-mail : kdmoon@knu.ac.kr, Phone : +82-53-950-5773, Fax : +82-53-950-6772

Received 15 February 2021; Revised 13 April 2021; Accepted 13 May 2021.

Copyright (c) The Korean Society of Food Preservation.

This is an Open Access article distributed under the terms of the Creative Commons Attribution Non-Commercial License (http://creativecommons.org/licenses/by-nc/4.0) which permits unrestricted non-commercial use, distribution, and reproduction in any medium, provided the original work is properly cited. 
인 것을 미루어 보아, 연근의 가공식품 개발은 농가소득을 향 상시키고, 원료의 부가가치를 올릴 수 있을 것으로 보인다. 연근(Nelumbo nucifera $\mathrm{G}$.)은 수련과 다년생 수생 식물인 연 (蓮)의 비대해진 뿌리로, 인도와 중국 등에서 유래하였다 (Kim, 2006). 연근의 품종은 비중종과 지방백화종이 있는데, 현재 우리나라에는 비중종이 보급되고 있으며, 가장 많이 재 배되고 있는 연근은 인도에서 유래한 만생종이다(Kim 등, 2002). 연근은 아삭한 식감으로 인해 주로 식용으로 사용하 였으며, 연잎, 연자육과 함께 약용으로도 이용되었으며, 우리 나라에서 연근은 생식을 하거나, 정과, 조림, 찜, 전, 죽 등의 요리에 주로 사용한다. 또는 건조시킨 후 차로 이용되거나, 전분제조에 이용되기도 한다(Kim 등, 2014). 연근의 주성분 은 탄수화물이고, 식물성 섬유가 풍부하다. 이 식물성 섬유는 장벽을 자극하고 장내활동을 활발하게 해주어 변비와 비만 예방 효과가 있으며, 체내의 콜레스테롤 수치를 낮추는 작용 을 한다. 또한 연근에 함유된 타닌은 혈관수축 작용과 지혈작 용을 하며, 염증을 억제하여 궤양, 해소, 빈혈 치료에 효과가 있다고 알려져 있다(Jung과 Shin, 1990).

현재 연근을 첨가한 가공품에 대한 연구는 연근 분말을 첨 가한 쿠키의 품질 특성(Lee 등, 2011), 연근가루 첨가량에 따 른 연근절편의 품질 특성(Kang과 Yoon, 2008), 연근가루를 첨가한 설기 떡의 품질 특성(Yoon과 Choi, 2008), 연잎과 연 근분말을 첨가한 스펀지케이크의 품질 특성(Kim 등, 2011), 동결건조 연근 분말을 첨가한 머핀의 품질 특성(Kim과 Kang, 2012), 연근 추출물을 첨가한 약과(Kim과 Kim, 2019), 동결 건조 연근 분말을 첨가한 연근 죽(Choi 등, 2019)에 관한 것 들이 있다. 이들은 주재료가 아닌 첨가물로서 가공식품에 적용 된 것이며, 제품의 큰 비율을 차지하지 않는다. 연근을 직접 가공한 연구로는 연근정과의 재료 및 조리방법(Cho 등, 1984), 연근 음료(Cho, 2016; Kim 등, 2011b)에 관한 연구가 있다. 가공 식품 중에서도 스낵(snack) 종류는 '가벼운 식사'를 뜻 하는 말로서 하루 세끼의 주식 이외에 가볍게 먹을 수 있는 식품을 말하며, 동서양과 같은 지역과 신세대, 기성세대와 같 은 연령대를 불문하고 간식 또는 술안주 등으로 즐겨먹는 식 품가공품의 한 종류이다(Kang 등, 2007). 이러한 스낵은 연 근을 직접적으로 섭취할 수 있으며, 본연의 맛과 영양을 쉽게 접할 수 있다. 또한 다른 가공식품에 비하여, 연근 소비량을 현저하게 증가시킬 수 있는 가공품이라고 할 수 있다. 그러나 최근까지 판매되고 있는 스낵의 대부분은 곡류를 주로 이용 하고 있고, 근채류는 감자와 고구마를 이용한 제품이 대부분 인 실정이다. 또한 연근을 직접 가공한 스낵에 관한 연구 보 고는 미비한 실정이다. 스낵을 제조하는 방식으로는 일반적 으로 건조, 구움, 튀김 등이 있으며, 이들의 가공 조건들은 향 과 맛을 좌우하게 된다. 본 연구에서 적용된 열처리 가공방법 으로는 오븐가열, 마이크로웨이브, 에어 프라이어, 유탕처리
가 있으며, 이들의 특징은 다음과 같다. 오븐의 경우 열원 종 류에 따라 컨벡션 오븐, 전기오븐, 가스오븐, 광파오븐 등이 있으며, 컨벡션 오븐은 가장 기본적인 형태로, 내부의 위아래 로 히터와 가열선이 설치되어 팬에 고루 열이 전달되도록 하 는 원리로 구동된다. 전자레인지라고도 불리는 마이크로웨이 브는 마이크로파에 의하여 식품 중 음전하와 양전하를 띄는 분자들의 전계 방향이 바뀔 때 발생하는 마찰에너지를 열원 으로 사용하는 가열조리 기구이다(Yoon 등, 2015). 이는 조 리가 편리하고, 시간 및 노동력을 절감할 수 있다는 장점이 있다(Kim, 1997). 에어 프라이어의 기본 원리는 내부의 팬으 로 외부에서 흡입한 공기를 열선을 이용해 열풍을 만든 후, 대류 구조를 사용하여 음식 주위로 고온의 공기를 고속으로 순환시켜 조리하는 방식이다(Khatir 등, 2013). 튀김, 즉 유탕 처리는 식품산업에 가장 많이 사용되는 방법 중 하나로 식용 유지를 매개체로 하여 고온에서 단시간 가열하는 조리법으 로, 식품 표면의 바삭바삭한 조직감, 흡수된 유지의 부드러운 맛과 독특한 향미를 부여한다(Chu와 Luo, 1994; Jeon 등, 2008; Son과 Kang, 2012).

따라서 본 연구에서는 오븐가열, 마이크로웨이브, 에어 프 라이어, 유탕처리 4가지의 열처리 방식으로 여러 온도 및 시 간 조건에 따라 연근스낵을 제조하고, 그것의 일반성분 및 품 질 특성 평가를 실시하여 연근스낵 제조에 적합한 열처리 방 법을 탐색하고자 하였다.

\section{재료 및 방법}

\section{재료 및 스낵 제조}

본 실험에 사용된 연근은 경상남도 함안군에서 생산된 것 을 구입하여 모양은 휘지 않고 곧으며, 무게가 약 $400 \mathrm{~g}$ 이며, 표면에 흠집이나 곰팡이 오염이 없는 상태가 양호한 것을 선 별하여 사용하였다. 연근 스낵을 제조하기 위하여 먼저 전처 리를 수행하였다. 선별된 연근 표면의 훍을 흐르는 물로 세척 후 박피한 후 일반적인 칼을 이용하여 $1 \mathrm{~mm}$ 두께로 일정하 게 절단하였다. $3 \%$ 농도의 소금물 $1 \mathrm{~L}$ 에 절단한 조각 60 개씩 5 분간 침지하고, 외부의 바람이 없는 상온 $\left(20 \pm 5^{\circ} \mathrm{C}\right)$ 환경에서 자연건조 후 연근 표면의 물기가 제거된 것을 스낵 제조에 사용하였다. 연근스낵의 제조방법은 오븐가열 $(\mathrm{OV})$, 마이크 로웨이브(MW), 에어프라이어(AF), 유탕처리(FR) 방법을 설 정하였다. 예비 실험을 통하여 각 열처리 방법별로 적합한 제 조 조건을 선정하였으며, 그 조건은 다음과 같다. $\mathrm{OV}$ 방법으 로 $180^{\circ} \mathrm{C}$ 와 $190^{\circ} \mathrm{C}$ 에서 $7,8,9 \mathrm{~min}$ 동안 처리 되었으며, $\mathrm{MW}$ 방법은 $850 \mathrm{~W}$ 에서 $2,4,6,8,10,12 \mathrm{~min}$ 동안 처리되었다. $\mathrm{AF}$ 는 $120^{\circ} \mathrm{C}$ 와 $140^{\circ} \mathrm{C}$ 에서 $6,8,10 \mathrm{~min}, \mathrm{FR}$ 은 $170^{\circ} \mathrm{C}$ 와 $180^{\circ} \mathrm{C}$ 에서 $60,70,80 \mathrm{sec}$ 동안 처리되었다. $\mathrm{OV}$ 에 의한 연근스낵 의 제조는 제방용 컨벤셔널 오븐(BL950903, Geumbok Stoke, 
Seoul, Korea)을 이용하여 윗불과 아랫불을 동일한 온도로 설 정하여 제조하였으며, $\mathrm{MW}$ 는 가정용 전자레인지(MH-641MG, $\mathrm{LG}$, Seoul, Korea)를 이용하였다. AF에 의한 연근 스낵은 에 어 프라이어(HD9230, Philips, Amsterdam, Netherlands)를 이 용하여 제조되었으며, $\mathrm{FR}$ 는 냄비에 식용유 $1 \mathrm{~L}$ 를 넣은 후 가 열하여, 조건에 따라 제조 후 스낵 표면 온도가 상온에 도달할 때까지 키친 타올 위에서 방냉한 것을 시료로 사용하였다.

\section{일반성분 분석}

생 연근 및 연근스낵의 수분, 조단백질, 조지방, 조회분 함 량은 각각 식품의약품안전처에서 고시한 식품공전의 일반시 험법을 변용하여 분석하였으며, 연근스낵의 일반성분 측정을 위하여 연근의 수분함량을 제외한 나머지 항목은 분말시료로 만들어 측정하였다. 분말 시료는 각각의 연근스낵을 분쇄기 (SNSG-1002SS, Hanil, Seoul, Korea)로 분쇄한 뒤, 40 mesh 로 걸러 얻었다. 수분함량은 식품공전 일반시험법의 2.1.1 조 항에 따라 $105^{\circ} \mathrm{C}$ 에서 상압 가열 건조법에 준하여 dry oven (KMC-1202D3, Vision Scientific Co., Daejeon, Korea)을 이 용하였으며, 다음의 식을 통해 산출되었다.

$$
\begin{gathered}
\text { 수분함량 }(\%)= \\
\text { 칭량접시와 검체의 무게 }(\mathrm{g})- \\
\frac{\text { 건조 후 항량이 되었을 때의 무게 }(\mathrm{g})}{\text { 칭량접시와 검체의 무게 }(\mathrm{g})-} \\
\text { 칭량접시의 무게 }(\mathrm{g})
\end{gathered}
$$

조단백질은 2.1.3.1 조항의 Kjeldahl 법을 사용하여, 질소자 동분석기(Nitrogen Autoanalyzer, Kjetec2400, Foss Analytical $\mathrm{A} / \mathrm{S}$, Hilleroed, Denmark)를 통해 분석되었다. 분해 장치에서 촉매의 존재 하에서 황산을 가하여, 지료의 질소를 황산암모 늄으로 가열분해한 뒤, 증류 및 적정장치를 통해 황산암모늄 에 $\mathrm{NaOH}$ 를 가하고, 포집액을 $\mathrm{NaOH}$ 로 적정하여 총 질소(\%) 를 구하고 다음의 식으로 조단백질 함량을 산출하였다.

$$
\text { 조단백질 }(\%)=\text { 총 질소 }(\%) \times \text { 질소계수 }
$$

조지방 함량은 일반시험법 2.1.5.1.1 조항에 따른 Soxhlet 추출법, 조섬유는 Henneberg-Stohmann 개량법에 의해 분석 하였고, 조회분은 2.1.4.2 조항에 따라 $600^{\circ} \mathrm{C}$ 의 회화로에서 직접 회화법으로 분석하였다. Neutral detergent fiber의 정량 은 AACC(American Association of Cereal Chemist)에 의하 여 공인된 방법인 Van Soest와 Wine의 방법(1967)으로 정량 하였다. 각 분석 결과는 3 회 반복하여 얻은 평균값으로 나타
내었다. 모든 결과 값은 무게를 기준으로 하여 $\%$ 단위로 나 타내었다.

\section{색도 측정}

연근과 연근스낵의 색도는 표준 백색판 $\left(\mathrm{L}^{*}=97.79, \mathrm{a}^{*}=-0.38\right.$, $\left.\mathrm{b}^{*}=2.05\right)$ 으로 보정된 Colorimeter(CR-400, Konica Minolta Co., Osaka, Japan)를 사용하였다. 각 열처리 조건별로 제조 한 연근스낵을 임의로 선택한 후, 연근 특성상 구멍 부분을 피하여 스낵의 단면 부분을 20 회 반복 측정한 후 평균값을 이용했으며, $L *$ 는 lightness, $a *$ 는 redness, $b^{*}$ 는 yellowness 를 의미한다.

\section{경도 측정}

스낵의 경도는 소비자들의 기호도에 큰 영향을 미치는 요소 중 하나이다. 경도는 Rheometer(Compac-100II, SunScientific Co., Tokyo, Japan)를 이용하여 측정하였다. 샘플 높이와 너 비는 각각 $1 \mathrm{~mm}$ 와 $10 \mathrm{~mm}$ 로 설정하였으며, test type은 hardness, strength였으며, adaptor는 직경 $25 \mathrm{~mm}$ 의 원형 타 입을 설치하여 측정하였다. Table speed는 $60 \mathrm{~mm} / \mathrm{min}$ 으로 설정하였으며, 10 회 반복 측정한 후 평균값을 이용했다.

\section{관능평가}

열처리 방법별로 최적의 조건을 선정하기 위하여, 관능평 가를 실시하였다. 연근 스낵의 관능평가는 9점 척도법으로 절 대평가 하도록 진행했으며, 사전 교육을 충분히 받은 20-30대 남녀로 구성된 경북대학교 학생 15 명을 패널로 선발하여 진 행하였다. 색(color), 경도(hardness), 쓴맛(bitterness) 항목은 강도가 높을수록 높은 점수를 부여하게 하였으며, 외관 (appearance), 바삭함(crispness), 맛(taste), 종합적 기호도 (overall acceptance)에 대한 항목은 기호도가 높을수록 높은 점수를 부여하도록 했다. 본 관능평가는 경북대학교 생명윤 리심의위원회에서 최종 면제(접수번호: KNU-2021-0001)를 통지 받고 안전하게 진행하였다.

\section{총페놀성 화합물 함량 측정}

연근 스낵의 총페놀성 화합물은 Folin-Ciocalteu 법 (Benvenuti 등, 2004)을 응용하여 측정하였다. 시료를 분말로 제조한 후, 분말 시료 $1 \mathrm{~g}$ 을 $70 \%$ 에탄올 $9 \mathrm{~mL}$ 를 가하여 초 음파 발생기(DH.WUC.D22H, Daihan Scientific Co., Ltd., Wonju, Korea)에서 20분간 추출한 후 원심분리기(1580MGR, GYROZEN, Daejeon, Korea)를 이용하여 9,000 rpm에서 30 분간 원심분리한 후 상등액을 취하였다. 일정비율로 희석한 상등액 용액에 50\% Folin-Ciocalteau reagent(Junsei Chemical Co., Ltd., Tokyo, Japan) $0.5 \mathrm{~mL}$ 와 혼합하여 15 분간 방치하 
였다. 다음 $10 \% \mathrm{Na}_{2} \mathrm{CO}_{3} 0.5 \mathrm{~mL}$ 를 가하여 1 시간 동안 반응 시켜 UV-visible spectrophotometer(Evolution 201, Thermo Fisher Scientific Inc, Madison, WI, USA)로 $760 \mathrm{~nm}$ 에서 흡 광도를 측정하였으며, tannic acid를 표준물질로 하여 총페놀 성 화합물 함량(mg TAE\%)을 나타내었다.

\section{항산화 활성 측정}

연근 스낵의 항산화 활성을 측정하기 위하여 1,1-diphenyl2-picrylhydrazyl(DPPH) 라디칼 소거능과 2,2'-azino-bis(3ethylbenzothiazoline-6-sulfonic acid(ABTS) 라디칼 소거능법 을 이용하였다. DPPH 라디칼 소거능 측정은 Blois의 방법을 변용하여(1958), DPPH에 대한 전자 공여능으로 DPPH 라디 칼 소거능을 이용하여 측정하였다. 분말화한 시료 $1 \mathrm{~g}$ 을 $70 \%$ 에탄올 $9 \mathrm{~mL}$ 를 가하여 초음파 발생기(DH.WUC.D22H, Daihan-Scientific Co., Ltd.)에서 20분간 추출 후 9,000 rpm 에서 30 분간 원심 분리한 상등액을 증류수로 희석한 것을 시 료용액으로 하였다. 시료 용액을 취하여 흡광도 값이 $1.00 \pm$ 0.02 가 되도록 ethanol로 보정한 후 DPPH 용액을 가하여 10 초 간 진탕하고, 10 분간 방치한 뒤 UV-visible spectrophotometer (Evolution 201, Thermo Fisher Scientific Inc.)를 사용하여 $525 \mathrm{~nm}$ 에서 흡광도를 측정하였다. DPPH 라디칼 소거능은 다음 식으로 나타내었다.

DPPH radical scavenging activity $(\%)=$

$$
\frac{\text { blank absorbance - sample absorbance }}{\text { blank absorbance }} \times 100
$$

$\mathrm{ABTS}$ 라디칼 소거능 측정은 Re 등(1999)의 방법을 변용 하여 측정하였다. $7.4 \mathrm{mM} \mathrm{ABTS}$ 용액에 $2.45 \mathrm{mM}$ potassium persulphate를 혼합한 후, 암소에 14시간 동안 방치하였다. 다 음 $734 \mathrm{~nm}$ 에서 흡광도가 1.00 이하가 되도록 희석한 후 시료용 액을 가하여 10 분간 방치하고, UV-visible spectrophotometer (Evolution 201, Thermo Fisher Scientific Inc.)로 734 nm에 서 흡광도를 측정하였다. ABTS 라디칼 소거능은 다음 식 으로 나타내었다.

ABTS radical scavenging activity $(\%)=$ blank absorbance - sample absorbance blank absorbance 100

\section{수분흡수지수 및 수분용해지수 측정}

열처리 방법을 달리한 연근스낵의 수분흡수지수(water absorption index, WAI)와 수분용해지수(water solubility index,
WSI)값의 측정은 Anderson(1982)과 Shin 등(2013)의 방법 을 변용하여 측정하였다. 분말화한 연근스낵 $2 \mathrm{~g}$ 에 증류수 30 $\mathrm{mL}$ 를 가하여 혼합한 후 원심분리기(1580MGR, GYROZEN) 를 이용하여 $9,000 \mathrm{rpm}$ 으로 10 분간 원심분리 하였다. 원심분 리 후 상등액을 항량된 수기에 옮겨 dry oven (KMC-1202D3, Vision Scientific Co.)에서 $105^{\circ} \mathrm{C}$ 로 가열하여 수분을 제거한 후 남은 고형분량을 이용하여 WSI를 측정하였으며, 상등액 을 제거한 침전물의 무게를 측정하여 $\mathrm{WAI}$ 를 측정하였다.

$$
\begin{aligned}
& \text { 수분흡수지수 }(\mathrm{WAI})=\frac{\text { 침전물의 양 }(\mathrm{g})}{\text { 시료량 }(\mathrm{g})} \times 100 \\
& \text { 수분용해지수 }(\mathrm{WSI})=\frac{\text { 상등액의 고형분량 }(\mathrm{g})}{\text { 시료량 }(\mathrm{g})} \times 100
\end{aligned}
$$

\section{통계처리}

실험 결과는 3 회 이상 반복 측정한 평균치로 나타내었으므 로 결과 간 유의성을 확인하기 위하여, SAS 9.4(Statistical Analysis System, SAS Institute, Cary, NC, USA)를 이용하 여 분산분석의 Duncan's multiple rage test $(\mathrm{p}<0.05)$ 통계처리 를 실시하였다.

\section{결과 및 고찰}

\section{원료의 품질특성}

본 실험에 사용된 원료 연근의 품질특성 분석 결과는 Table 1에 무게에 대한 \%로 제시하였다. 원료 연근은 수분 $76.68 \%$, 조지방 $0.96 \%$, 조단백질 $7.77 \%$, 조회분 $4.57 \%$, 탄 수화물 $10.02 \%$ 총 불용성 식이 섬유량은 $2.40 \%$ 로 나타났다. 이전 연구에서 $\mathrm{Bae}$ 등(2008)은 연근의 수분함량을 $76.57 \%$, Hwang 등(2014)은 조회분과 조단백질 함량을 각각 $4.75 \%$, $7.42 \%$ 로 보고하여 본 연구 결과와 흡사했다. 연근의 색도 측 정 결과, 명도를 나타내는 $\mathrm{L}^{*}$ 은 63.33 , 적색도를 나타내는 $\mathrm{a}^{*}$ 는 0.30 , 황색도를 나타내는 $b^{*}$ 는 5.35 로 나타났으며, 경도는 $14.28 \mathrm{~g}$ 중 $/ \mathrm{cm}^{2}$ 이었다.

Jang 등(2012)은 $55^{\circ} \mathrm{C}$ 열수에 처리한 연근의 저장 중 색도 를 측정하였다. 저장 0 일차에 $\mathrm{L}^{*}, \mathrm{a}^{*}$ 값 결과가 본 연구 결과 와 유사하였고, 열처리에 의한 변색으로 $b^{*}$ 값은 약 11 로 나 타나 본 결과와 상이하였다.

총 페놀성 화합물 함량 분석 결과는 $220.17 \mathrm{mg} \%$ 로 나타 났다. 페놀성 화합물은 식물에 분포되어 있는 2 차 대사산물 로 다양한 구조를 가지고 있어 구조에 따른 생리활성 기능을 가지는데(Cha와 Cho, 1999), 이 페놀성 화합물의 역할은 자 유라디칼을 소거하는 것으로 알려져 있다. 호흡과정에서 들 
Table 1. Quality characteristics of lotus root

\begin{tabular}{llc}
\hline & Moisture & $76.68 \pm 0.42^{1)}$ \\
& Crude fat & $0.96 \pm 0.07$ \\
$\left.\begin{array}{l}\text { Proximate } \\
\text { composition }\end{array}\right)$ & Crude protein & $7.77 \pm 0.03$ \\
& Crude ash & $4.57 \pm 0.11$ \\
& Carbohydrate & $10.02 \pm 0.46$ \\
& Neutral detergent fiber & $2.40 \pm 0.10$ \\
\hline & Lightness (L*) & $63.33 \pm 2.98$ \\
Color value & Redness (a*) & $0.30 \pm 0.29$ \\
& Yellowness (b*) & $5.35 \pm 0.58$ \\
\hline Hardness (g/cm $\left.{ }^{2}\right)$ & $14.28 \pm 3.15$ \\
\hline Total phenolics (mg TAE\%) & $220.17 \pm 3.65$ \\
\hline Antioxidant & DPPH radical scavenging & $76.71 \pm 0.36$ \\
activity (\%) & ABTS radical scavenging & $76.74 \pm 0.85$ \\
\hline
\end{tabular}

${ }^{1)}$ Values are Mean \pm SD $(\mathrm{n}=3)$.

여 마신 산소 중 일부분(약 2-3\%)은 활성산소(자유라디칼)라 고 하는 유독 작용을 하는 물질로 전환되어 생체에 큰 장해를 일으키는 것으로 알려져 있다(Oyanagui, 1989). 자유라디칼 은 노화경로에 관여할 뿐만 아니라, 각 조직의 염증반응, 동맥 경화, 심혈관 질환, 면역체계 관련 등의 질병을 유발시킨다 (Halliwell과 Gutteridge, 1984). 페놀성 화합물은 이러한 질병 의 예방과 치료에 쓰이는 항산화 물질로 알려져 있다(Shahidi
등, 1992).

원료 연근의 항산화 활성 분석 결과, DPPH 및 $\mathrm{ABTS}$ 라디 칼 소거능은 각각 $76.61 \%, 76.74 \%$ 로 나타났다. $\mathrm{DPPH}$ 라디 칼 소거능은 안정한 자유라디칼인 $\mathrm{DPPH}$ 가 전자를 공여할 수 있는 항산화 물질과 반응하여 본래의 자색이 탈색되며 나 타내는 지표이며(Choi 등, 2003), ABTS 라디칼 소거능은 $\mathrm{ABTS}$ 와 potassium persulfate와의 반응에 의하여 생성된 $\mathrm{ABTS}$ 라디칼이 항산화 물질과 반응하여 ABTS 라디칼의 색 인 청록색이 탈색되는 것을 이용한 방법(Rha 등, 2014)이다. 이 두 가지 방법은 항산화 활성측정에 흔히 이용되는 방법이 다. $\mathrm{Kim}$ 등(2015)은 박피된 연근의 DPPH 라디칼 소거능이 $80.74 \%$ 라고 보고하여, 본 연구 결과와 유사하였다. Lee 등 (2015)은 DPPH 라디칼 소거능은 연근이 도라지보다 3배 이 상 우수한 것으로 나타났다고 언급하였다.

\section{최적 열처리 조건 설정}

예비 실험에서 색도와 경도를 분석하여 최적의 연근 열처 리 방법 및 조건을 설정하였다. 식품에서 색과 경도는 관능적 품질에 영향을 미치는 중요한 요인 중 하나이다. 색도와 경도 의 분석 결과는 Table 2에 표시하였으며, 그 외관은 Fig. 1에 나타내었다. 열처리 방법에 관계없이 제조시간이 길수록, 온 도가 높을수록 $\mathrm{L}^{*}$ 값은 감소하고, $\mathrm{a}^{*}$ 값과 $\mathrm{b}$ *값은 증가하는 경향을 나타내었다. 특히 $\mathrm{OV} 190^{\circ} \mathrm{C}(9 \mathrm{~min}), \mathrm{MW} 850 \mathrm{~W}(12$ $\mathrm{min}), \mathrm{AF} 140^{\circ} \mathrm{C}(10 \mathrm{~min}), \mathrm{FR} 180^{\circ} \mathrm{C}(80 \mathrm{sec})$ 처리구는 다른 처리구들에 비하여 급격히 색이 어두워졌는데, 이는 가열 시 높은 온도와 긴 시간으로 처리하여 탄화 과정이 진행되었고,

Table 2. Color value and hardness of lotus root snacks heated with different methods and conditions

\begin{tabular}{|c|c|c|c|c|c|c|}
\hline Treatment $^{1)}$ & $\begin{array}{l}\text { Temp. }\left({ }^{\circ} \mathrm{C}\right) \\
\text { power }(\mathrm{W})\end{array}$ & Time & $\mathrm{L}^{*}$ & $a^{*}$ & $b^{*}$ & Hardness $\left(\mathrm{g} / \mathrm{cm}^{2}\right)$ \\
\hline \multirow{6}{*}{ OV } & \multirow{3}{*}{$180^{\circ} \mathrm{C}$} & $7 \mathrm{~min}$ & $54.69 \pm 3.61^{2) a 3)}$ & $1.00 \pm 2.10^{\mathrm{d}}$ & $15.22 \pm 4.75^{\mathrm{c}}$ & $29.54 \pm 7.21^{\mathrm{b}}$ \\
\hline & & $8 \mathrm{~min}$ & $50.64 \pm 5.41^{\mathrm{b}}$ & $3.21 \pm 2.27^{\mathrm{c}}$ & $17.95 \pm 3.73^{b}$ & $46.73 \pm 19.70^{\mathrm{ab}}$ \\
\hline & & $9 \min$ & $48.36 \pm 3.30^{\mathrm{b}}$ & $4.28 \pm 0.92^{\mathrm{bc}}$ & $22.56 \pm 2.23^{\mathrm{a}}$ & $53.59 \pm 30.11^{\mathrm{a}}$ \\
\hline & \multirow{3}{*}{$190^{\circ} \mathrm{C}$} & $7 \mathrm{~min}$ & $53.40 \pm 3.26^{\mathrm{a}}$ & $1.42 \pm 1.76^{\mathrm{d}}$ & $15.65 \pm 3.43^{\mathrm{c}}$ & $51.02 \pm 16.22^{\mathrm{a}}$ \\
\hline & & $8 \mathrm{~min}$ & $47.31 \pm 4.44^{\mathrm{c}}$ & $4.74 \pm 2.06^{\mathrm{b}}$ & $21.26 \pm 3.33^{\mathrm{a}}$ & $44.68 \pm 21.80^{\mathrm{ab}}$ \\
\hline & & $9 \min$ & $38.55 \pm 5.00^{\mathrm{d}}$ & $10.46 \pm 1.42^{\mathrm{a}}$ & $21.47 \pm 3.31^{\mathrm{a}}$ & $64.28 \pm 26.62^{\mathrm{a}}$ \\
\hline \multirow{6}{*}{ MW } & \multirow{6}{*}{$850 \mathrm{~W}$} & $2 \mathrm{~min}$ & $62.48 \pm 1.89^{\mathrm{a}}$ & $-0.99 \pm 0.11^{\mathrm{e}}$ & $6.92 \pm 1.26^{\mathrm{d}}$ & $3.49 \pm 1.21^{\mathrm{d}}$ \\
\hline & & $4 \mathrm{~min}$ & $58.50 \pm 1.36^{\mathrm{b}}$ & $1.14 \pm 0.83^{\mathrm{d}}$ & $16.51 \pm 1.86^{\mathrm{c}}$ & $11.88 \pm 4.28^{\mathrm{d}}$ \\
\hline & & $6 \mathrm{~min}$ & $52.31 \pm 6.41^{\mathrm{c}}$ & $1.02 \pm 1.13^{\mathrm{d}}$ & $16.85 \pm 3.78^{\mathrm{c}}$ & $64.94 \pm 8.13^{\mathrm{bc}}$ \\
\hline & & $8 \mathrm{~min}$ & $51.94 \pm 6.48^{\mathrm{c}}$ & $3.27 \pm 2.29^{\mathrm{c}}$ & $19.95 \pm 3.46^{\mathrm{b}}$ & $67.39 \pm 26.09^{c}$ \\
\hline & & $10 \mathrm{~min}$ & $51.10 \pm 4.75^{\mathrm{c}}$ & $5.20 \pm 2.12^{\mathrm{b}}$ & $22.37 \pm 3.65^{\mathrm{a}}$ & $50.61 \pm 16.76^{\mathrm{a}}$ \\
\hline & & $12 \mathrm{~min}$ & $42.84 \pm 7.64^{\mathrm{d}}$ & $8.25 \pm 1.80^{\mathrm{a}}$ & $24.00 \pm 2.73^{\mathrm{a}}$ & $97.92 \pm 27.49^{c}$ \\
\hline
\end{tabular}


(continued)

\begin{tabular}{|c|c|c|c|c|c|c|}
\hline Treatment $^{1)}$ & $\begin{array}{l}\left.\text { Temp. ( }{ }^{\circ} \mathrm{C}\right) \\
\text { /power (W) }\end{array}$ & Time & $\mathrm{L}^{*}$ & $a^{*}$ & $b^{*}$ & Hardness $\left(\mathrm{g} / \mathrm{cm}^{2}\right)$ \\
\hline \multirow{6}{*}{$\mathrm{AF}$} & \multirow{3}{*}{$120^{\circ} \mathrm{C}$} & $6 \mathrm{~min}$ & $69.02 \pm 5.22^{\mathrm{a}}$ & $-0.42 \pm 0.34^{\mathrm{d}}$ & $7.51 \pm 1.61^{\mathrm{e}}$ & $8.45 \pm 3.01^{\mathrm{b}}$ \\
\hline & & $8 \min$ & $62.45 \pm 2.53^{\mathrm{b}}$ & $-0.12 \pm 0.39^{d}$ & $8.71 \pm 0.77^{\mathrm{e}}$ & $47.76 \pm 10.17^{b}$ \\
\hline & & $10 \mathrm{~min}$ & $54.70 \pm 4.11^{\mathrm{c}}$ & $0.84 \pm 0.62^{\mathrm{c}}$ & $12.09 \pm 1.83^{\mathrm{c}}$ & $56.90 \pm 16.64^{\mathrm{b}}$ \\
\hline & \multirow{3}{*}{$140^{\circ} \mathrm{C}$} & $6 \min$ & $59.19 \pm 3.22^{b}$ & $-0.16 \pm 0.53^{\mathrm{d}}$ & $10.23 \pm 1.65^{\mathrm{d}}$ & $49.18 \pm 13.94^{\mathrm{b}}$ \\
\hline & & $8 \mathrm{~min}$ & $55.80 \pm 8.44^{\mathrm{c}}$ & $2.56 \pm 1.58^{\mathrm{b}}$ & $13.40 \pm 2.66^{\mathrm{b}}$ & $50.04 \pm 18.97^{\mathrm{b}}$ \\
\hline & & $10 \mathrm{~min}$ & $45.35 \pm 5.79^{\mathrm{d}}$ & $6.66 \pm 1.39^{\mathrm{a}}$ & $16.54 \pm 2.93^{\mathrm{a}}$ & $108.90 \pm 34.11^{\mathrm{a}}$ \\
\hline \multirow{6}{*}{ FR } & \multirow{3}{*}{$170^{\circ} \mathrm{C}$} & $60 \mathrm{sec}$ & $49.34 \pm 2.03^{\mathrm{a}}$ & $-0.33 \pm 0.22^{\mathrm{e}}$ & $11.46 \pm 1.21^{\mathrm{d}}$ & $13.29 \pm 5.35^{\mathrm{a}}$ \\
\hline & & $70 \mathrm{sec}$ & $42.20 \pm 4.01^{\mathrm{bc}}$ & $1.43 \pm 0.70^{\mathrm{d}}$ & $17.91 \pm 2.36^{\mathrm{c}}$ & $47.49 \pm 26.46^{\mathrm{a}}$ \\
\hline & & $80 \mathrm{sec}$ & $40.43 \pm 3.15^{\mathrm{c}}$ & $6.89 \pm 1.28^{\mathrm{b}}$ & $23.35 \pm 1.39^{\mathrm{a}}$ & $65.51 \pm 22.21^{\mathrm{a}}$ \\
\hline & \multirow{3}{*}{$180^{\circ} \mathrm{C}$} & $60 \mathrm{sec}$ & $42.91 \pm 2.57^{\mathrm{b}}$ & $2.27 \pm 1.30^{\mathrm{c}}$ & $18.33 \pm 2.71^{\mathrm{c}}$ & $20.33 \pm 3.34^{\mathrm{a}}$ \\
\hline & & $70 \mathrm{sec}$ & $42.02 \pm 2.76^{\mathrm{bc}}$ & $2.80 \pm 0.72^{\mathrm{c}}$ & $21.45 \pm 2.35^{\mathrm{b}}$ & $93.76 \pm 23.47^{\mathrm{a}}$ \\
\hline & & $80 \mathrm{sec}$ & $34.67 \pm 2.78^{\mathrm{d}}$ & $10.18 \pm 1.20^{\mathrm{a}}$ & $23.06 \pm 2.18^{\mathrm{a}}$ & $67.89 \pm 7.44^{\mathrm{a}}$ \\
\hline
\end{tabular}

${ }^{1)} \mathrm{OV}$, oven heating; MW, microwave heating; $\mathrm{AF}$, air fryer heating; $\mathrm{FR}$, oil frying heating.

${ }^{2)}$ Values are Mean \pm SD $(n=3)$.

${ }^{3)}$ Means with different letters in the same column are significantly different by Duncan's multiple range test $(\mathrm{p}<0.05)$

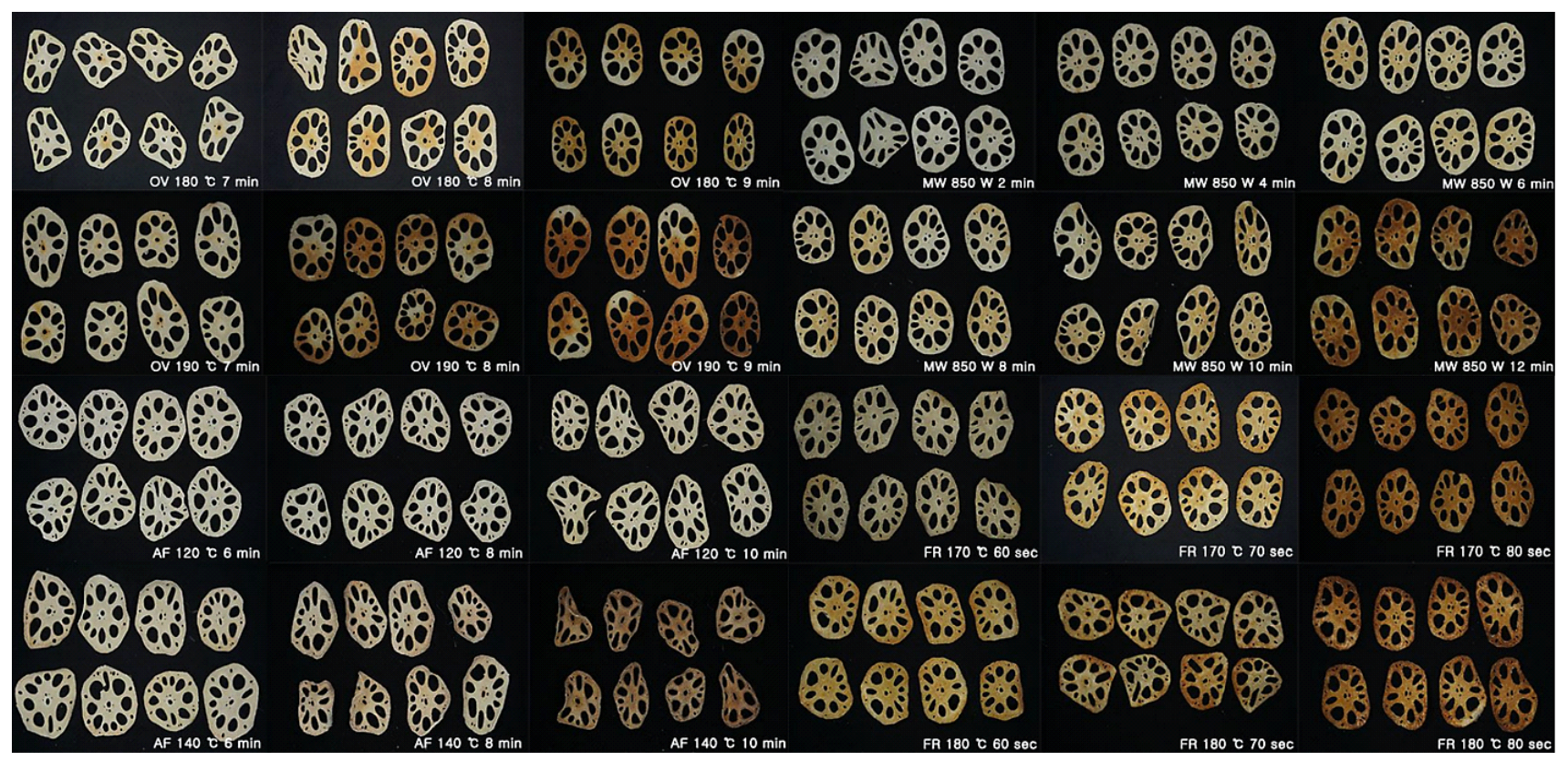

Fig. 1. Photographs of lotus root snacks processed by various heat treatments and conditions.

$\mathrm{OV}$, oven heating; MW, microwave heating; AF, air fryer heating; FR, oil frying heating.

갈변 물질이 발생하였기 때문이다. 가열로 인하여 당, 아미노 산의 중합반응이 발생하여 갈변 물질이 생겨나며, 이는 가열 온도가 높을수록, 가열시간이 길어질수록 가용성 성분은 감
소하고, 갈변 물질은 증가하는 것으로 알려져 있다(Lee 등, 2009).

또한 가열 온도가 높고 처리 시간이 길수록 경도 값이 높 
아지는 경향을 나타내었는데, 일반적으로 식품의 경도는 수 분함량과 연관이 있는데 일반적으로 수분함량이 높을수록 경 도가 낮은 것으로 알려져 있다(Njintang 등, 2006). 가열로 인 하여 수분함량이 감소하여 조직의 경화가 일어나, 처리온도와 시간에 따라 경도가 증가한 것으로 보인다. 반면, FR $180^{\circ} \mathrm{C}$ 처리구의 경우, 유탕처리 시간에 따라 경도가 급격히 증가하 다가 감소하였다. 유탕 과정 중 연근의 수분이 증발한 자리에 발생한 기공 내부로 기름이 침투해 들어가는 흡유 현상 (Suderman 등, 1981)이 일어났을 것으로 보인다. 유탕처리
시간이 짧을 때는 흡유 현상이 이상적으로 이루어져, 바삭한 식감을 잘 나타냄으로 경도가 높아졌다. 하지만 유탕처리 시 간이 길어지면서 연근에 과도한 기공이 발생하고 더 많은 기 름이 흡수됨으로써 조직의 밀도와 견고성이 떨어지고, 많은 양의 기름으로 인해 바삭한 식감보다는 눅눅한 식감이 발생 하면서 경도가 감소하였을 것으로 보인다.

열처리 방법별로 최적의 조건을 선정하기 위하여, 관능평 가를 실시한 결과는 Table 3에 표시하였다. 전반적으로 제조 방법에 관계없이 가열 온도가 높을수록, 가열 시간이 길수록

Table 3. Sensory scores of lotus root snacks heated with different methods and conditions

\begin{tabular}{|c|c|c|c|c|c|c|c|c|c|}
\hline Treatment $^{1)}$ & $\begin{array}{c}\text { Temperature/ } \\
\text { power }\end{array}$ & Time & Color & Hardness & Bitterness & Appearance & Crispness & Taste & $\begin{array}{c}\text { Overall } \\
\text { acceptability }\end{array}$ \\
\hline \multirow{6}{*}{ OV } & \multirow{3}{*}{180} & $7 \mathrm{~min}$ & $2.67 \pm 1.84^{2) b 3)}$ & $3.67 \pm 2.35^{\mathrm{b}}$ & $1.87 \pm 1.25^{\mathrm{c}}$ & $4.20 \pm 1.90^{\mathrm{b}}$ & $1.33 \pm 0.49^{\mathrm{c}}$ & $3.33 \pm 1.50^{\mathrm{c}}$ & $2.27 \pm 1.33^{\mathrm{d}}$ \\
\hline & & $8 \mathrm{~min}$ & $3.87 \pm 1.46^{\mathrm{b}}$ & $4.07 \pm 1.94^{\mathrm{b}}$ & $2.20 \pm 1.52^{\mathrm{c}}$ & $5.27 \pm 2.28^{\mathrm{b}}$ & $2.73 \pm 1.28^{\mathrm{b}}$ & $3.73 \pm 1.53^{\mathrm{bc}}$ & $3.53 \pm 1.88^{\mathrm{cd}}$ \\
\hline & & $9 \mathrm{~min}$ & $5.87 \pm 1.96^{\mathrm{a}}$ & $4.60 \pm 1.76^{\mathrm{ab}}$ & $2.47 \pm 1.25^{\mathrm{c}}$ & $7.73 \pm 1.44^{\mathrm{a}}$ & $7.20 \pm 1.32^{\mathrm{a}}$ & $6.73 \pm 1.79^{\mathrm{a}}$ & $8.13 \pm 0.99^{\mathrm{a}}$ \\
\hline & \multirow{3}{*}{190} & $7 \mathrm{~min}$ & $3.47 \pm 1.64^{b}$ & $4.53 \pm 2.90^{\mathrm{ab}}$ & $2.20 \pm 1.57^{\mathrm{c}}$ & $5.07 \pm 1.87^{\mathrm{b}}$ & $1.87 \pm 0.92^{\mathrm{b}}$ & $3.40 \pm 1.55^{\mathrm{c}}$ & $3.80 \pm 1.97^{\mathrm{c}}$ \\
\hline & & $8 \mathrm{~min}$ & $6.00 \pm 1.31^{\mathrm{a}}$ & $5.20 \pm 1.97^{\mathrm{ab}}$ & $3.73 \pm 1.79^{b}$ & $4.13 \pm 1.77^{b}$ & $6.80 \pm 1.82^{\mathrm{a}}$ & $4.87 \pm 2.26^{\mathrm{b}}$ & $6.27 \pm 2.02^{\mathrm{b}}$ \\
\hline & & $9 \mathrm{~min}$ & $6.87 \pm 2.85^{\mathrm{a}}$ & $6.13 \pm 2.07^{\mathrm{a}}$ & $6.33 \pm 1.95^{\mathrm{a}}$ & $2.40 \pm 1.18^{\mathrm{c}}$ & $6.47 \pm 2.29^{\mathrm{a}}$ & $3.47 \pm 1.51^{\mathrm{c}}$ & $4.00 \pm 2.51^{\mathrm{c}}$ \\
\hline \multirow{6}{*}{ MW } & \multirow{6}{*}{850} & $2 \mathrm{~min}$ & $1.67 \pm 0.98^{\mathrm{e}}$ & $2.27 \pm 1.62^{\mathrm{c}}$ & $2.53 \pm 2.00^{\mathrm{b}}$ & $2.80 \pm 1.66^{\mathrm{c}}$ & $1.33 \pm 0.62^{\mathrm{d}}$ & $2.67 \pm 1.40^{\mathrm{b}}$ & $2.13 \pm 1.19^{c}$ \\
\hline & & $4 \mathrm{~min}$ & $2.93 \pm 0.96^{\mathrm{d}}$ & $3.67 \pm 1.99^{\mathrm{b}}$ & $2.87 \pm 2.45^{\mathrm{b}}$ & $3.60 \pm 1.45^{\mathrm{c}}$ & $2.47 \pm 0.83^{\mathrm{c}}$ & $3.80 \pm 1.15^{\mathrm{b}}$ & $3.20 \pm 1.21^{\mathrm{bc}}$ \\
\hline & & $6 \mathrm{~min}$ & $4.40 \pm 1.30^{\mathrm{c}}$ & $5.80 \pm 1.21^{\mathrm{a}}$ & $3.00 \pm 1.89^{\mathrm{b}}$ & $5.13 \pm 1.36^{\mathrm{b}}$ & $6.73 \pm 1.49^{b}$ & $6.20 \pm 1.61^{\mathrm{a}}$ & $6.67 \pm 1.50^{\mathrm{a}}$ \\
\hline & & $8 \mathrm{~min}$ & $5.00 \pm 1.20^{\mathrm{c}}$ & $5.67 \pm 1.76^{\mathrm{a}}$ & $2.93 \pm 1.58^{\mathrm{b}}$ & $7.00 \pm 1.51^{\mathrm{a}}$ & $7.60 \pm 0.91^{\mathrm{a}}$ & $6.67 \pm 1.68^{\mathrm{a}}$ & $7.27 \pm 1.03^{\mathrm{a}}$ \\
\hline & & $10 \mathrm{~min}$ & $6.07 \pm 1.16^{\mathrm{b}}$ & $6.20 \pm 1.86^{\mathrm{a}}$ & $3.80 \pm 2.24^{\mathrm{b}}$ & $6.13 \pm 1.51^{\mathrm{ab}}$ & $7.60 \pm 1.24^{\mathrm{a}}$ & $6.40 \pm 1.55^{\mathrm{a}}$ & $6.40 \pm 1.72^{\mathrm{a}}$ \\
\hline & & $12 \mathrm{~min}$ & $8.13 \pm 0.74^{\mathrm{a}}$ & $6.93 \pm 2.09^{\mathrm{a}}$ & $6.13 \pm 2.29^{\mathrm{a}}$ & $3.80 \pm 1.90^{\mathrm{c}}$ & $8.07 \pm 1.22^{\mathrm{a}}$ & $3.67 \pm 2.09^{\mathrm{b}}$ & $3.33 \pm 2.29^{\mathrm{b}}$ \\
\hline \multirow{6}{*}{$\mathrm{AF}$} & \multirow{3}{*}{120} & $6 \mathrm{~min}$ & $2.13 \pm 1.55^{\mathrm{c}}$ & $3.00 \pm 2.36^{\mathrm{c}}$ & $3.60 \pm 2.32^{\mathrm{b}}$ & $4.07 \pm 1.91^{\mathrm{b}}$ & $1.27 \pm 0.46^{\mathrm{e}}$ & $2.33 \pm 0.98^{\mathrm{d}}$ & $2.07 \pm 0.70^{\mathrm{c}}$ \\
\hline & & $8 \mathrm{~min}$ & $3.00 \pm 1.25^{\mathrm{c}}$ & $3.87 \pm 1.68^{\mathrm{bc}}$ & $2.47 \pm 1.19^{\mathrm{b}}$ & $3.53 \pm 1.60^{\mathrm{b}}$ & $3.47 \pm 1.77^{\mathrm{d}}$ & $4.13 \pm 1.55^{\mathrm{abc}}$ & $4.27 \pm 1.71^{\mathrm{ab}}$ \\
\hline & & $10 \mathrm{~min}$ & $4.60 \pm 1.24^{\mathrm{b}}$ & $4.33 \pm 1.68^{\mathrm{bc}}$ & $3.33 \pm 1.95^{\mathrm{b}}$ & $5.87 \pm 2.07^{\mathrm{a}}$ & $4.40 \pm 1.50^{\mathrm{c}}$ & $4.53 \pm 1.30^{\mathrm{abc}}$ & $5.33 \pm 1.88^{\mathrm{a}}$ \\
\hline & \multirow{3}{*}{140} & $6 \mathrm{~min}$ & $4.87 \pm 0.92^{\mathrm{b}}$ & $4.40 \pm 1.88^{\mathrm{bc}}$ & $3.60 \pm 2.26^{\mathrm{b}}$ & $6.07 \pm 1.03^{\mathrm{a}}$ & $3.27 \pm 1.39^{\mathrm{d}}$ & $3.53 \pm 1.25^{\mathrm{bc}}$ & $3.73 \pm 1.03^{\mathrm{b}}$ \\
\hline & & $8 \mathrm{~min}$ & $6.67 \pm 1.11^{\mathrm{a}}$ & $5.27 \pm 1.10^{\mathrm{ab}}$ & $3.67 \pm 2.19^{b}$ & $6.53 \pm 1.41^{\mathrm{a}}$ & $5.73 \pm 1.03^{b}$ & $4.80 \pm 1.57^{\mathrm{abc}}$ & $5.27 \pm 1.62^{\mathrm{a}}$ \\
\hline & & $10 \mathrm{~min}$ & $6.93 \pm 2.71^{\mathrm{a}}$ & $6.07 \pm 2.28^{\mathrm{a}}$ & $5.73 \pm 2.15^{\mathrm{a}}$ & $2.93 \pm 1.16^{\mathrm{b}}$ & $7.73 \pm 0.88^{\mathrm{a}}$ & $3.13 \pm 1.55^{\mathrm{cd}}$ & $3.40 \pm 2.38^{\mathrm{b}}$ \\
\hline \multirow{6}{*}{ FR } & \multirow{3}{*}{170} & $60 \mathrm{sec}$ & $2.40 \pm 1.35^{\mathrm{c}}$ & $3.13 \pm 2.17^{b}$ & $2.73 \pm 2.19^{\mathrm{b}}$ & $3.80 \pm 2.04^{\mathrm{c}}$ & $1.93 \pm 1.10^{\mathrm{c}}$ & $4.07 \pm 1.28^{\mathrm{b}}$ & $2.87 \pm 1.30^{\mathrm{b}}$ \\
\hline & & $70 \mathrm{sec}$ & $5.07 \pm 1.79^{\mathrm{b}}$ & $5.27 \pm 2.12^{\mathrm{a}}$ & $2.47 \pm 1.68^{\mathrm{b}}$ & $6.40 \pm 1.18^{\mathrm{a}}$ & $6.67 \pm 1.40^{\mathrm{a}}$ & $6.27 \pm 1.44^{\mathrm{a}}$ & $6.60 \pm 1.40^{\mathrm{a}}$ \\
\hline & & $80 \mathrm{sec}$ & $5.53 \pm 2.00^{\mathrm{ab}}$ & $5.67 \pm 1.80^{\mathrm{a}}$ & $2.73 \pm 1.71^{\mathrm{b}}$ & $4.87 \pm 2.13^{\mathrm{bc}}$ & $7.47 \pm 0.92^{\mathrm{a}}$ & $6.40 \pm 1.72^{\mathrm{a}}$ & $6.33 \pm 2.13^{\mathrm{a}}$ \\
\hline & \multirow{3}{*}{180} & $60 \mathrm{sec}$ & $4.60 \pm 1.35^{\mathrm{b}}$ & $5.27 \pm 1.53^{\mathrm{a}}$ & $2.60 \pm 1.68^{\mathrm{b}}$ & $5.60 \pm 1.40^{\mathrm{ab}}$ & $5.47 \pm 1.64^{\mathrm{b}}$ & $5.93 \pm 1.28^{\mathrm{a}}$ & $5.47 \pm 1.60^{\mathrm{a}}$ \\
\hline & & $70 \mathrm{sec}$ & $6.00 \pm 1.51^{\mathrm{ab}}$ & $5.87 \pm 2.00^{\mathrm{a}}$ & $2.67 \pm 1.63^{\mathrm{b}}$ & $6.80 \pm 1.26^{\mathrm{a}}$ & $7.40 \pm 0.91^{\mathrm{a}}$ & $6.40 \pm 1.06^{\mathrm{a}}$ & $6.80 \pm 1.82^{\mathrm{a}}$ \\
\hline & & $80 \mathrm{sec}$ & $6.73 \pm 2.74^{\mathrm{a}}$ & $5.40 \pm 2.59^{\mathrm{a}}$ & $5.67 \pm 1.63^{\mathrm{a}}$ & $3.80 \pm 1.78^{\mathrm{c}}$ & $7.33 \pm 1.35^{\mathrm{a}}$ & $4.53 \pm 1.68^{b}$ & $4.07 \pm 2.05^{\mathrm{b}}$ \\
\hline
\end{tabular}

${ }^{1)} \mathrm{OV}$, oven heating; MW, microwave heating; $\mathrm{AF}$, air fryer heating; FR, oil frying heating.

${ }^{2)}$ Values are Mean \pm SD $(\mathrm{n}=3)$.

${ }^{3}$ Means with different letters in the same column are significantly different by Duncan's multiple range test $(p<0.05)$. 
색이 진해지고, 경도가 높아지며, 쓴맛이 증가하는 양상을 보 였다. 이는 색도 경도 측정 결과와 일치하였으며, 장시간 높은 온도 처리는 탄화과정을 진행시켜 쓴맛을 증가시켰을 것으로 보인다. 외관, 바삭함, 맛, 전반적 기호도 항목에서 $\mathrm{OV}\left(180^{\circ} \mathrm{C}\right.$, $9 \mathrm{~min})$ 처리구, $\mathrm{MW}(850 \mathrm{~W}, 8 \mathrm{~min})$ 처리구, $\mathrm{FR}\left(180^{\circ} \mathrm{C}, 70\right.$ $\mathrm{sec}$ ) 처리구가 각 열처리 방법에서 높은 점수를 받았고, $\mathrm{AF}$ 처리구에서는 전반적 기호도 항목에서 $120^{\circ} \mathrm{C}, 8 \mathrm{~min}$ 처리구 와 $140^{\circ} \mathrm{C}, 8 \mathrm{~min}$ 가 각각 5.33점과 5.27점으로 유의적 차이 없이 가장 높은 점수를 얻었다. 이와 같은 관능평가 결과를 종합하여 가장 높은 기호도 점수를 받은 처리구인 $\mathrm{OV}(18$ $\left.0^{\circ} \mathrm{C}, 9 \mathrm{~min}\right), \mathrm{MW}(850 \mathrm{~W}, 8 \mathrm{~min}), \mathrm{FR}\left(180^{\circ} \mathrm{C}, 70 \mathrm{~s}\right), \mathrm{AF}(12$ $\left.0^{\circ} \mathrm{C}, 10 \mathrm{~min}\right)$ 처리구들을 각 제조 방법별 적합한 제조조건으 로 선정하였다.

\section{열처리 방법에 따른 연근스낵의 품질 특성}

앞서 선정된 각 열처리 방법별 최적 열처리 조건 $\mathrm{OV}\left(180^{\circ} \mathrm{C}\right.$, $9 \mathrm{~min}), \mathrm{MW}(850 \mathrm{~W}, 8 \mathrm{~min}), \mathrm{AF}\left(120^{\circ} \mathrm{C}, 10 \mathrm{~min}\right), \mathrm{FR}\left(180^{\circ} \mathrm{C}\right.$, $70 \mathrm{sec})$ 에서 연근 스낵을 제조하고, 각 방법에 따른 연근 스 낵의 품질 특성을 비교하였다. 다양한 열처리 방법으로 제조 된 연근스낵의 일반성분 분석 결과는 Table 4에 표시하였다. 수분함량은 $\mathrm{AF}$ 처리구가 $5.60 \%$ 로 가장 높은 함량을 나타나 수분 증발이 가장 적은 것으로 확인되었으며, $\mathrm{OV}(3.00 \%)$, MW (4.26\%), FR(0.77\%)로 나타났다. Lee 등(2013)과 Jeon 등(2008)에 따르면 가열된 튀김유는 열을 전달하는 매체로 작용하게 되는데, 이 때 연근으로 전달된 열에 의해 연근 속 의 수분은 수증기로 변하여 수분함량은 감소하고, 이 때 생 긴 공간으로 튀김유가 흡수된다고 보고하였다. 따라서 FR 처리구의 수분함량이 나머지 처리구보다 낮은 것은 이와 같 이 고온의 튀김유에 의한 수분의 급격한 감소로 인한 것으로
판단된다.

조단백질 함량은 $\mathrm{OV}$ 처리구가 $8.62 \%$ 로 가장 높은 함량 을, $\mathrm{FR}(4.41 \%)$ 는 가장 낮은 함량을 나타내었으며, 제조 방법 에 따라 유의적인 차이가 나타났다. 조회분 함량 역시 $\mathrm{OV}$ 처리구가 $6.35 \%$ 로 가장 높았으며, FR 처리구는 $3.52 \%$ 로 가 장 낮은 함량을 보였다. 조지방 함량은 유의적 차이는 없었으 나, $\mathrm{AF}$ 와 $\mathrm{MW}$ 가 낮은 조지방 함량을 보였다. Air frying은 기기 내부의 뜨거운 공기를 이용하여 식품 주위에 미세한 오 일 미스트를 직접 접촉시켜 튀김 식품을 제조하는 방법이며, 기존의 튀김(deep fat frying)에 비해 저지방 식품을 제공한다 고 보고된 바 있다(Teruel 등, 2015). Tian 등(2017)은 air frying 식품이 기존의 튀김 방법에 비해 기름 흡수율은 낮고 관능적 특성이 높았다고 보고하였으며, 소비자들에게 건강한 식품을 제공하는데 튀김의 대체 방법이 될 수 있다고 언급한 바 있다. 총 불용성 식이섬유 함량은 $\mathrm{FR}(10.17 \%), \mathrm{MW}$ (7.18\%), $\mathrm{OV}(6.53 \%), \mathrm{AF}(5.68 \%)$ 순으로 나타났으며, 유의 적 차이가 있었다. $\mathrm{AF}$ 가 가장 낮은 불용성 식이섬유를 함유 하며, 이로 인해 소비자가 섭취했을 때 소화흡수율이 높을 것 으로 보인다. Kye(2014)는 채소를 열처리함으로써 총 불용성 식이섬유 함량이 증가한다고 보고하였는데, 본 연구에서도 원료 생 연근(2.40\%)에 비해 높은 값을 나타냈다. 특히 FR 처리구가 가장 큰 폭으로 총 불용성 식이섬유 함량이 증가하 였는데, Kye(1995)는 채소류를 stir-frying 하였을 때, 수분의 현저한 감소로 인하여, 총 불용성 식이섬유 함량이 높게 나왔 다고 보고한 바와 일치하였다.

\section{열처리 방법에 따른 연근스낵의 수분흡수지수 및 수분용해 지수 \\ 수분흡수지수와 수분용해지수는 연근 스낵의 수용성 성질}

Table 4. Proximate composition of lotus root snacks processed by different heating methods

\begin{tabular}{|c|c|c|c|c|}
\hline \multirow{2}{*}{$\begin{array}{l}\text { Proximate composition } \\
\qquad(\%)\end{array}$} & \multicolumn{4}{|c|}{ Treatment $^{1)}$} \\
\hline & OV & MW & $\mathrm{AF}$ & FR \\
\hline Moisture & $3.00 \pm 0.09^{2)(3)}$ & $4.26 \pm 0.10^{\mathrm{b}}$ & $5.60 \pm 0.49^{\mathrm{a}}$ & $0.77 \pm 0.09^{\mathrm{d}}$ \\
\hline Crude protein & $8.62 \pm 0.07^{\mathrm{a}}$ & $4.61 \pm 0.09^{\mathrm{c}}$ & $7.90 \pm 0.15^{\mathrm{b}}$ & $4.41 \pm 0.02^{\mathrm{d}}$ \\
\hline Crude fat & $0.97 \pm 0.02^{\mathrm{a}}$ & $0.60 \pm 0.05^{\mathrm{b}}$ & $0.65 \pm 0.04^{b}$ & $0.92 \pm 0.05^{\mathrm{a}}$ \\
\hline Crude ash & $6.35 \pm 0.26^{\mathrm{a}}$ & $4.99 \pm 0.12^{\mathrm{b}}$ & $4.93 \pm 0.24^{b}$ & $3.52 \pm 0.22^{\mathrm{c}}$ \\
\hline Carbohydrate & $81.06 \pm 0.16^{\mathrm{c}}$ & $85.54 \pm 0.23^{b}$ & $80.91 \pm 0.53^{\mathrm{c}}$ & $90.38 \pm 0.25^{\mathrm{a}}$ \\
\hline Neutral detergent fiber & $6.53 \pm 0.05^{\mathrm{c}}$ & $7.18 \pm 0.37^{\mathrm{b}}$ & $5.68 \pm 0.49^{\mathrm{d}}$ & $10.17 \pm 0.05^{\mathrm{a}}$ \\
\hline
\end{tabular}

\footnotetext{
${ }^{1)} \mathrm{OV}$, oven heating at $180^{\circ} \mathrm{C}$ for 9 mins; MW, microwave heating at $850 \mathrm{~W}$ for 8 mins; $\mathrm{AF}$, air frying at $120^{\circ} \mathrm{C}$ for 10 mins; FR, oil frying at $180^{\circ} \mathrm{C}$ for $70 \mathrm{sec}$.

${ }^{2)}$ Values are Mean \pm SD $(n=3)$.

${ }^{3)}$ Means with different letters in the same row are significantly different by Duncan's multiple range test $(\mathrm{p}<0.05)$.
} 
을 분석한 것으로, 호화도와 팽화율에 영향을 받으며, 스낵 제품으로서 이들 수치는 높을수록 좋은 품질로 인정된다(Lee 와 Kim, 1994). 각 열처리 방법 중 최적의 조건에서 제조된 연근스낵의 수분흡수지수(WAI)와 수분용해지수(WSI) 값은 Fig. 2에 제시하였다. WAI 값은 $\mathrm{OV}$ 와 $\mathrm{MW}$ 처리구에서 각각 $5.15,5.12$ 로 가장 높은 값을 보였으며, 이들은 $\mathrm{FR}$ 과 $\mathrm{AF}$ 보다 유의적으로 높은 값을 보였다. WAI는 전분과 단백질의 수화 를 나타내는 지표이며(Mason과 Hoseney, 1986), 이 수분흡 착지수의 증가 요인은 전분 용융물이 취약해져 수분을 흡수 하기 쉬운 기공이 많은 조직으로 변화되었기 때문이라고 보 고된 바 있다(Lee 등, 2011). 또한 젤라틴화된 샘플에서 WAI 가 매우 높은 것은 손상되지 않은 긴 폴리머 chain 구조가 존재하기 때문이며, 고분자 chain의 길이가 줄어들면 WAI가 감소하고, WSI는 반대로 증가하는 양상을 보인다(Gomez와 Aguilera, 1984). WSI는 전분의 붕괴에서 발생하는 수용성 물질의 양에 비례하며(Jeong 등, 2002), Tie 등(2008)은 호화 도가 증가할수록 수분용해지수가 높다고 보고하였다. Shin 등(2009)은 가공처리 과정에서 전분분해가 더 많이 이루어져
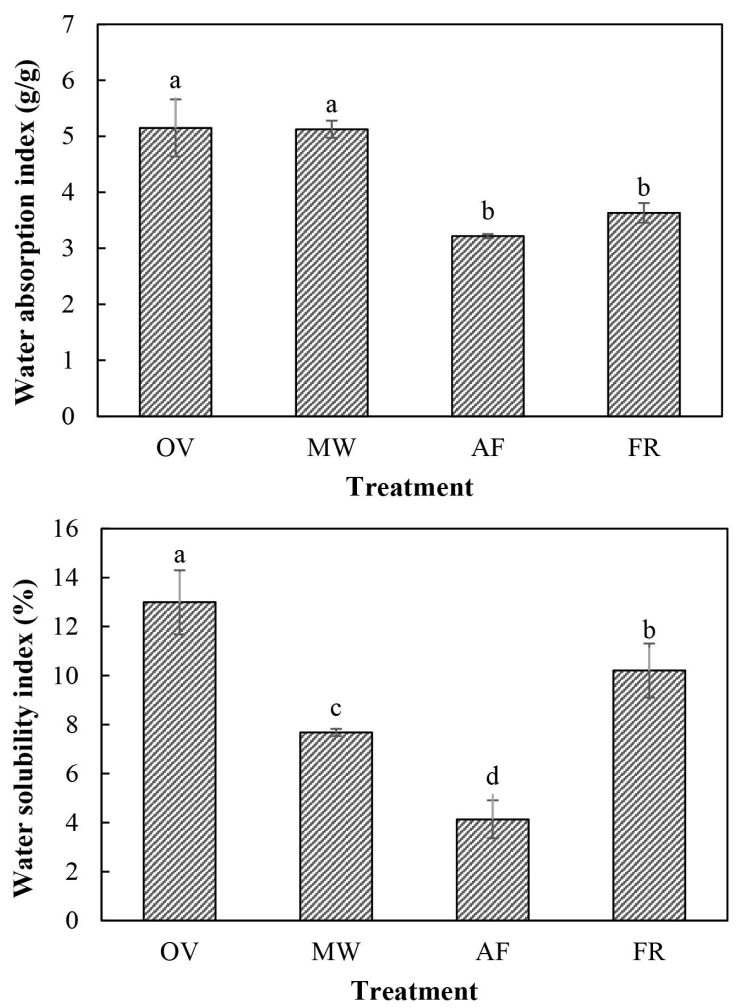

Fig. 2. Water absorption index and water solubility index of lotus root snacks processed by different heating methods.

$\mathrm{OV}$, oven heating at $180^{\circ} \mathrm{C}$, for 9 mins; $\mathrm{MW}$, microwave heating at $850 \mathrm{~W}$, for 8 mins; $\mathrm{AF}$, air frying at $120^{\circ} \mathrm{C}$, for 10 mins; FR, oil frying at $180^{\circ} \mathrm{C}$, for $70 \mathrm{sec}$

Means $(n=3)$ with different letters are significantly different $(p<0.05)$. soluble matrix가 증가함에 따라 WSI가 증가한다고 보고했으 며, 따라서 $\mathrm{OV}$ 처리구와 $\mathrm{FR}$ 처리구는 연근의 전분 분해 현 상이 유의적으로 많이 나타난 것으로 보인다.

\section{열처리 방법에 따른 연근스낵의 총페놀성 화합물 및 항산화 활성}

Fig. 3은 연근스낵의 총페놀성 화합물과 항산화 활성을 나 타낸 것이다. 총페놀성 화합물 함량은 $\mathrm{AF}$ 처리구가 현저히
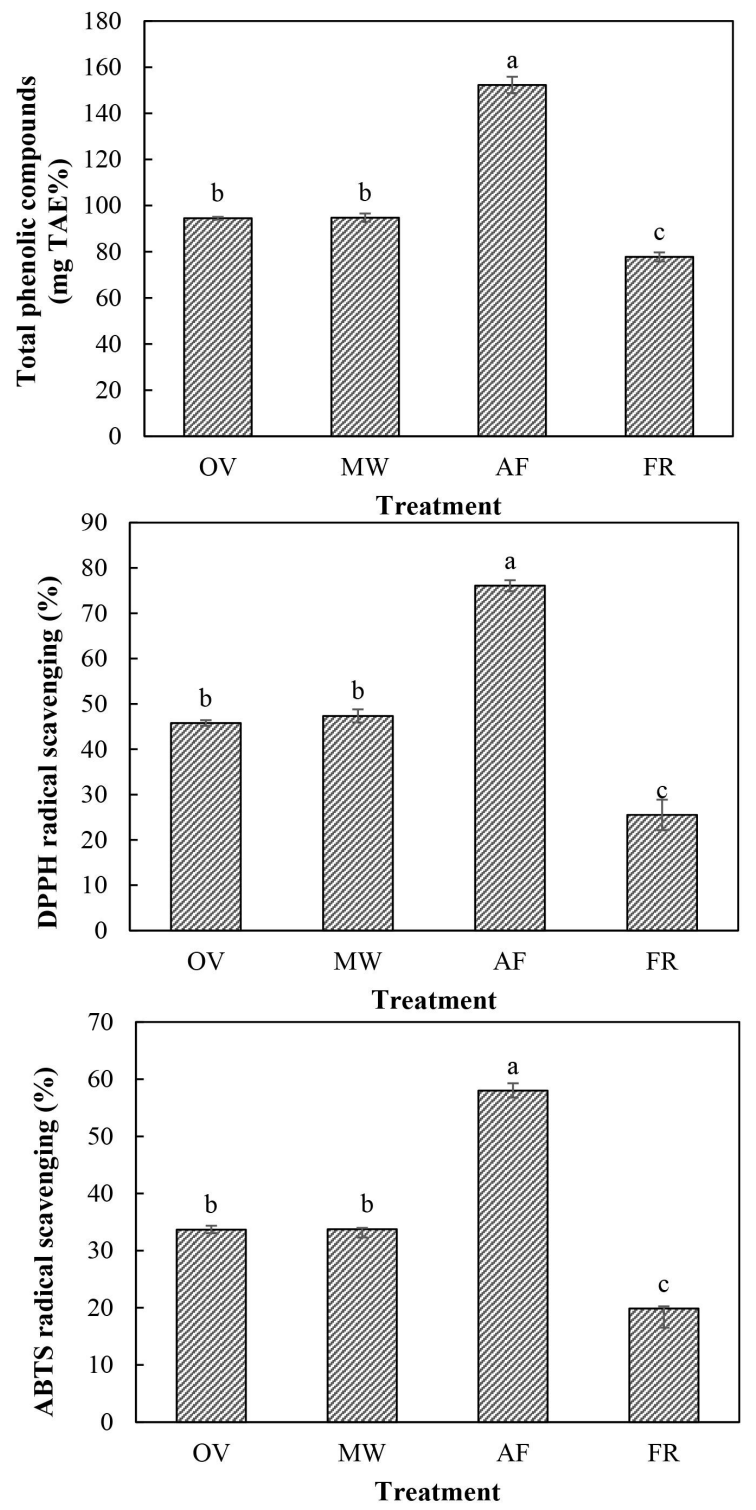

Fig. 3. Total phenolics contents and antioxidant activitys of lotus root snacks processed by different heating methods.

CONT, non-treatment; OV, oven heating at $180^{\circ} \mathrm{C}$, for 9 mins; MW, microwave heating at $850 \mathrm{~W}$, for $8 \mathrm{mins} ; \mathrm{AF}$, air frying at $120^{\circ} \mathrm{C}$, for 10 mins; FR, oil frying at $180^{\circ} \mathrm{C}$, for $70 \mathrm{sec}$.

Means $(n=3)$ with different letters are significantly different $(p<0.05)$. 
높게 나타나는 것을 확인할 수 있었으며, $\mathrm{OV}$ 와 $\mathrm{MW}$ 는 서로 유사한 값을 보였다. FR는 $77.76 \mathrm{mg} / 100 \mathrm{~g}$ 으로 가장 낮은 함량 을 나타냈다. 페놀성 화합물은 갈변 효소인 PPO (polyphenol oxidase)의 기질로 작용한다고 알려져 있는데(Hwang 등, 2009), 연근스낵의 색도에서도 나타났듯이 갈변 정도가 상대 적으로 높은 $\mathrm{OV}, \mathrm{MW}, \mathrm{FR}$ 처리구가 $\mathrm{AF}$ 보다 페놀성 화합물 이 낮은 현상은 이에 기인하였다고 사료된다. 연근스낵의 $\mathrm{DPPH}$ 및 $\mathrm{ABTS}$ 라디칼 소거능 측정 결과는 총 페놀 화합물 함량 측정 결과와 유사한 경향을 나타냈으며, $\mathrm{AF}$ 처리구에서 각각 $76.09 \%, 57.99 \%$ 로 가장 높은 $\mathrm{DPPH}$ 및 $\mathrm{ABTS}$ 라디칼 소거능을 나타냈다. 이러한 결과는 총 페놀성 화합물의 함량 은 $\mathrm{DPPH}$ 라디칼 소거능과 $\mathrm{ABTS}$ 라디칼 소거능과 밀접한 연관이 있다는 Wang 등(2003)의 보고와 일치하였다.

\section{요 약}

최근 소비자들의 건강에 대한 관심이 증대되면서 근채류 를 이용한 스낵 생산과 소비가 지속적으로 증가하고 있다. 연 근 생산량 및 생산면적은 계속 증가하고 있으나, 근채류 스낵 은 대부분 감자나 고구마에 한정되어 있는 실정이다. 따라서 본 연구에서는 기능성과 품질 높은 연근 스낵을 제조하기 위 해 적절한 가공법과 조건을 찾고자 하였다. 연근스낵의 가공 에 적합한 방법을 찾고자 오븐가열 $(\mathrm{OV})$, 마이크로웨이브 (MW), 에어 프라이어(AF), 유탕처리(FR) 등의 다양한 열처 리 방법, 가열 온도와 시간에 따라 연근스낵을 제조하였다. 색도와 경도를 측정하여 각 열처리 방법별 최적 조건에서 제 조된 연근 스낵의 품질 특성을 분석하고 비교하였다. 연근 스 낵은 열처리 방법과는 상관없이 가열온도가 높고 가열시간이 길수록, 명도는 감소하고 적색도와 황색도는 증가하는 경향 을 보였으며, 경도는 높아졌다. 최적의 조건으로 선택된 방법 은 $\mathrm{OV}\left(180^{\circ} \mathrm{C}, 9 \mathrm{~min}\right), \mathrm{MW}(850 \mathrm{~W}, 8 \mathrm{~min}), \mathrm{AF}\left(120^{\circ} \mathrm{C}, 10\right.$ $\mathrm{min}), \mathrm{FR}\left(180^{\circ} \mathrm{C}, 70 \mathrm{sec}\right)$ 처리구였다. 색도 분석 결과, $\mathrm{AF}$ 처 리구의 명도가 56.37로 가장 높았으며, 적색도 및 황색도는 $\mathrm{OV}$ 처리구에서 각각 $5.65,20.53$ 으로 가장 높게 나타났다. 경도는 $\mathrm{FR}$ 처리구가 $91.98 \mathrm{~g}$ 중 $/ \mathrm{cm}^{2}$ 으로 가장 높았으며, 나머 지 처리구들끼리는 유의적 차이를 보이지 않았다. 수분흡수 지수 분석 결과, $\mathrm{OV}(5.15), \mathrm{MW}(5.12), \mathrm{FR}(3.63), \mathrm{AF}(3.22)$ 순 으로 높게 나왔으며, 수분용해지수는 OV(12.99\%), FR(10.21\%), $\mathrm{MW}(7.68 \%), \mathrm{AF}(4.13 \%)$ 순으로 나타났다. 식품의 기능성이 라 할 수 있는 총페놀성 화합물, 항산화 활성 분석 결과, $\mathrm{AF}$ 처리구에서 유의적으로 높게 나타났다. 따라서 색도가 밝고, 경도가 적당하며, 수분흡수지수는 낮고, 항산화성이 높게 나 타난 $\mathrm{AF}\left(120^{\circ} \mathrm{C}, 10 \mathrm{~min}\right)$ 방법이 연근 스낵을 제조하는데 가 장 적절한 방법인 것으로 사료된다.

\section{Conflict of interests}

The authors declare no potential conflict of interest.

\section{ORCID}

Ji-Young Choi https://orcid.org/0000-0002-7854-9277 Kwang-Deog Moon https://orcid.org/0000-0001-5277-3345

\section{References}

Anderson RA. Water absorption and solubility and amylograph characteristics of roll-cooked small grain products. Cereal Chem, 59, 265-269 (1982)

Bae MJ, Kim SJ, Ye EJ, Nam HS, Park EM. Study on the chemical composition of lotus root and functional evaluation of fermented lotus root drink. J Korean Soc Food Cult, 23, 222-227 (2008)

Benvenuti S, Pellati F, Melegari M, Bertelli D. Polyphenols, anthocyanins, ascorbic acid, and radical scavenging activity of rubus, ribes, and aronia. J Food Sci, 69, 164-169 (2004)

Blois MS. Antioxidant determinations by the use of a stable free radical. Nature, 181, 1199-1200 (1958)

Cha JY, Cho YS. Effect of potato polyphenolics on lipid peroxidation in rats. J Korean Soc Food Sci Nutr, 28, 1131-1136 (1999)

Cho SH, Kang RK, Lee HG. A study on the ingredients preparation method of lotus root Jung Kwa. J Korean Soc Food Nutr, 13, 42-50 (1984)

Choi CH, Song ES, Kim JS, Kang MH. Antioxidantive activities of Castanea crenata flos. methanol extracts. Korean J Food Sci Technol, 35, 116-120 (2003)

Choi SY, Ko SH, Jeong HC. Antioxidant activities and physicochemical properties of porridge by freeze dried lotus root powder of different ratios. Culi Sci Hos Res, 25, 147-158 (2019)

Chu YH, Luo S. Effects of sugar, salt and water on soybean oil quality during deep-frying. J Am Oil Chem Soc, 71, 897-900 (1994)

Gomez MH, Aguilera JM. A physicochemical model for extrusion of corn starch. J Food Sci, 49, 40-43 (1984)

Halliwell B, Gutteridge JMC. Oxygen toxicity, oxygen radicals, transition metals and disease. Biochem J, 219, 
$1-14$ (1984)

Hwang DJ, Kang EJ, Kim JS, Kim KM. Effect of peeled lotus root on physicochemical properties. J East Asian Soc Dietary Life, 24, 793-801 (2014)

Hwang TY, Jang JH, Moon KD. Quality changes in freshcut potato (Solanum tuberosum var. Romano) after lowtemperature blanching and treatment with anti-browning agents. Korean J Food Preserv, 16, 499-505 (2009)

Jang MS, Park MJ, Kim JG, Kim GH. Effects of various packaging materials on the quality of heat treated lotus roots during storage. Korean J Food Preserv, 19, 807812 (2012)

Jeon MS, Kim JY, Lee JW, Lee KT. Changes in total transfatty acid content in soybean oil, shortening, and olive oil used for frying. J East Asian Soc Dietary Life, 18, 181-189 (2008)

Jeong HS, Min YK, Toledo RT. Effects of low temperature extrusion method on the physical properties and cell structure of pregelatinized rice flour extrudate. Food Eng Prog, 6, 145-151 (2002)

Jo SJ, Lee JE, Rho JO. Quality characteristics of lotus root tea added with Gardenia jasminoides powder and Rubus coreanus Miquel powder. J Korean Soc Food Cult, 31, 597-604 (2016)

Jung BS, Shin MG. Hyangyak-Seangyak Great Encyclopedia. Young-Lim Publishing Co, Seoul, Korea, p 439-443 (1990)

Kang JH, Yoon SJ. Quality characteristics of Julpyun containing different levels of lotus root powder. Korean J Food Cookery Sci, 24, 392-397 (2008)

Kang KT, Heu MS, Kim JS. Preparation and food component characteristics of snack using flatfish-frame. J Korean Soc Food Sci Nutr, 36, 651-656 (2007)

Khatir Z, Paton J, Thompson H, Kapur N, Toropov V. Optimisation of the energy efficiency of bread-baking ovens using a combined experimental and computational approach. Appl Energy, 112, 918-927 (2013)

Kim DH, Kang CS. Qualitative characteristics of muffins prepared with freeze dried lotus root powder. J Hotel Resort, 11, 5-15 (2012)

Kim HB, Chung HS, Moon KD. Browning inhibition of fresh-cut lotus roots by blanching in Glycyrrhiza glabra L. and Astragalus membranaceus Bunge extracts. Korean J Food Preserv, 21, 151-156 (2014)
Kim HS, Lee CH, Oh JW, Lee JH, Lee SK. Quality characteristics of sponge cake with added lotus leaf and lotus root powders. J Korean Soc Food Sci Nutr, 40, 1285-1291 (2011a)

Kim HY. Development of modified Jeung-pyun heated by microwave method. J Korean Soc Food Sci, Nutr, 26, 878-885 (1997)

Kim JM, Kim JS. Quality characteristics and antioxidants of Yakgwa added with lotus root extract. Culi Sci Hos Res, 25, 124-133 (2019)

Kim JS, Hwang DJ, Kang EJ, Kim KM, Choi SY, Kim GC. Antioxidant capacities and inhibitory activity on angiotension converting enzyme of dried lotus root by different pretreatment. J East Asian Soc Dietary Life, 25, 667-671 (2015)

Kim SH, Suk JE, Cho MS, Choi NS. Research on lotus root Eungi and development of beverage from lotus root starch. Korean J Food Culture, 26, 734-742 (2011b)

Kim YS, Jeon SS, Jung ST. Effect of lotus root powder on the baking quality of white bread. Korean J Food Cook Sci, 18, 413-425 (2002)

Kye SK. Effect of cooking on water in soluble dietary fiber in vegetables. Korean J Food Nutr, 8, 116-127 (1995)

Kye SK. Studies on composition of dietary fiber in vegetables. J East Asian Soc Dietary Life, 24, 28-41 (2014)

Lee BB, Lee JW, Park JW, Lee HJ, Chung YK. Effect of frying methods under reduced pressures on the quality of French fries. Korean J Food Nutr, 26, 60-65 (2013)

Lee KC, Kim YS, Ryu GH. Saccharification characteristics of extruded corn starch at different process parameters. Food Eng Prog, 15, 155-161 (2011)

Lee KS, Kim JN, Chung HC. Study on anti-oxidative activities and beverage preferences relating to fermented lotus root and Platycodon grandiflorum extracts with sugar through lactic acid fermentation. J East Asian Soc Dietary Life, 25, 183-192 (2015)

Lee KS, Kim MG, Lee KY. Antioxidative activity of ethanol extract from lotus (Nelumbo nucifera) leaf. J Korean Soc Food Sci Nutr, 35, 182-186 (2006)

Lee SH, Kim CK. Optimization for extrusion cooking conditions of rice extrudate by response surface methodology. Korean J Food Nutr, 7, 137-143 (1994)

Lee SH, Lee YR, Hwang IG, Woo KS, Kim KH, Kim KJ, Jeong HS. Antioxidant activities and quality characteristics 
of germinated rough rice tea according to roasting temperature, time and leaching condition. Korean J Food Sci Technol, 41, 386-391 (2009)

Mason WR, Hoseney RC. Factors affecting the viscosity of extrusion-cooked wheat starch. Cereal Chem, 63, 436441 (1986)

Njintang YN, Mbofung CMF. Effect of precooking time and drying temperature on the physico-chemical characteristics and in-vitro carbohydrate digestibility of taro flour. LWT-Food Sci Technol, 39, 684-691 (2006)

Oyanagui Y. SOD and Active Oxygen Modulators Pharmacology and Clinical Trials. Nihon- Igakukan, Tokyo, Japan, 129-278 (1989)

Re R, Pellegrini N, Proteggente A, Pannala A, Yang M, Rice-Evans C. Antioxidant activity applying and improved ABTS radical cation decolorization assay. Free Radic Biol Med, 26, 1231-1237 (1999)

Rha YA, Choi MS, Park SJ. Antioxidant and antiadipogenic effects of fermented Rhus verniciflua. Korean J Culinary Research, 20, 137-147 (2014)

Shahidi F, Janitha PK, Wanasundara PD. Phenolic antioxidants. Crit Rev Food Sci Nutr, 32, 67-103 (1992)

Shin DS, Yoo SM, Park BR. Effect of different steaming and drying temperature conditions on physicochemical characteristics of pumpkin powder. Korean J Food Sci Technol, 45, 742-746 (2013)

Shin MC, Kuo CC, Chiang W. Effects of drying and extrusion on colour, chemical composition, antioxidant activities and mitogenic response of spleen lymphocytes of sweet potatoes. Food Chem, 117, 114-121 (2009)

Son JY, Kang KO. Changes in quality properties of deep frying oil and fried chickens according to frying number.
J East Asian Soc Dietary Life, 22, $527-534$ (2012)

Suderman DR, Wiker J, Cunningham FE. Factors affecting adhesion of coating to poultry skin: Effects of various protein and gum sources in the coating composition. J Food Sci, 46, 1010-1011 (1981)

Teruel MR, Gordon M, Linares MB, Garrido MD, Ahromrit A, Niranjan K. A comparative study of the characteristics of French fries produced by deep fat frying and air frying. J Food Sci, 80, E349-E358 (2015)

Tian J, Chen S, Shi J, Chen J, Liu D, Cai Y, Ogawa Y, Ye X. Microstructure and digestibility of potato strips produced by conventional frying and air-frying: An in vitro study. Food Struct, 14, 30-35 (2017)

Tie J, Kim MH, Ryu HJ, Lee KH, Han MS, Cho SS, Lee HK, Ryu GH. Quality characteristics of rice cake (Injulmi) made with traditional process and instant Injulmi machine and different steeping time. Food Eng Prog, 12, 97-106 (2008)

Van Soest PJ, Wine RH. Use of detergents in the analysis of fibrous feeds. IV. Determination of plant cell-wall constituents. J Assoc Offic Anal Chem, 50, 50-54 (1967) Wang SY, Chang HN, Lin KT, Lo CP, Yang NS, Shyur LF. Antioxidant properties and phytochemical characteristics of extracts from Lactuca indica. J Agric Food Chem, 51, 1506-1512 (2003)

Yoon CS, Hong SI, Cho AR, Lee HS, Park HW, Lee KT. Analysis of the causes of deformation of packaging materials used for ready-to-eat foods after microwave heating. Korean J Food Sci Technol, 47, 63-69 (2015)

Yoon SJ, Choi BS. Quality characteristics of Sulgitteok added with lotus root powder. Korean J Food Cookery Sci, 24, 431-438 (2008) 